\title{
Peran Strategi Badan Wakaf Indonesia (BWI) dalam Meningkatkan Profesionalisme Nazhir Kota Semarang
}

\author{
Muhammad Budi Buchari Harahap1, Darwanto ${ }^{2}$ \\ Universitas Diponegoro', Universitas Diponegoro² \\ budibuchari@gmail.com
}

\begin{abstract}
Nazhir's problem is one of the problems in waqf practice that is often encountered in the management of waqf today. These obstacles are due to the low quality of human resources, lack of understanding of Nazhir, and lack of guidance given to Nazhir. This paper will discuss about the security of waqf in the city of Semarang, selling nazhir and implementing strategies by the Indonesian Waqf Board in order to create Nazhir professionalism. The purpose of this research is to find out the problems between waqf assets, Nazhir and the Indonesian Waqf Board and to formulate what solutions can solve them. This study uses a qualitative method with a descriptive approach, data observation, observation, and document review. The results showed that there were still many waqf assets found without complete administration so that representatives of BWI Central Java were focused on strategies to control existing waqf assets and the training received by Nazhirs in Semarang City was not sufficient to produce professional Nazirs. The mindset, understanding and work ethic of the Nazhirs are still traditional to create a productive climate of waqf which is beneficial for the economy of society.
\end{abstract}

Keywords: waqf, nazir, BWI

\begin{abstract}
Abstrak
Problematika nazhir menjadi salah satu permasalahan dalam praktik perwakafan yang kerap ditemui dalam pengelolaan wakaf dewasa ini. Kendala tersebut dikarenakan rendahnya kualitas sumber daya manusia, kurangnya pemahaman nazhir, kurangnya pembinaan yang diberikan kepada nazhir. Tulisan ini akan membahas tentang kendala perwakafan di Kota Semarang, kendala nazhir dan penerapan strategi oleh Badan Wakaf Indonesia agar terciptanya profesionalisme nazhir. Tujuan penelitian ini adalah mengetahui problematika antara aset wakaf, nazhir dan Badan Wakaf Indonesia serta rumusan solusi apa yang dapat menyelesaikannya. Penelitian ini menggunakan metode kualitatif dengan cara pendekatan deskriptif, pengumpulan data dengan wawancara, observasi, dan tinjauan dokumen. Hasil penelitian didapat bahwa masih banyak ditemukan aset wakaf tanpa adanya administrasi yang lengkap sehingga perwakilan BWI Jawa Tengah memfokuskan strategi melalui penertiban aset wakaf yang ada serta pelatihan yang didapat nazhir Kota Semarang belum cukup untuk melahirkan nazhir yang profesional. Pola pikir, pemahaman dan etos kerja para nazhir masih tradisional untuk tujuan menciptakan iklim perwakafan yang produktif bermanfaat demi ekonomi keumatan.
\end{abstract}

Keyword: Wakaf, Nazhir, BWI

\section{PENDAHULUAN}

Wakaf merupakan salah satu ibadah dalam agama Islam yang manfaat pahala kebaikannya akan tetap mengalir meskipun wakif (pihak yang mewakafkan harta benda miliknya) telah wafat. Hal tersebut disampaikan oleh Nabi 
Muhammad dalam hadits "Jika manusia mati, maka terputuslah amalnya kecuali tiga perkara: (1) sedekah jariyah, (2) ilmu yang diambil manfaatnya, (3) anak shalih yang selalu didoakan orang tuanya." (HR. Muslim, no. 1631). Yang dimaksud sedekah jariyah dalam hadits tersebut adalah kegiatan seperti membangun masjid, menggali sumur agar masyarakat dapat memanfaatkan airnya, menulis buku yang ilmunya dapat diambil orang terus-menerus. Oleh karena itu, berwakaf termasuk kegiatan sedekah jariyah yang akan menolong seseorang di akhirat nanti.

Praktik wakaf telah ditemukan sebelum masa Rasulullah Saw. Wakaf yang pertama kali dalam masyarakat Arab pra Islam adalah Al-Ka'bah Al-Musyarafah yaitu rumah peribadatan pertama yang dibangun oleh Nabi Ibrahim sebagai tempat untuk berkumpul (Haji) Nissa (2017). Ka'bah berfungsi sebagai pusat peribadatan serta sebagai kiblat sholat umat Islam seluruh dunia tanpa ada yang memilikinya. Dari zaman ke zaman, ka'bah sempat menjadi tempat dimana terdapat berhala-berhala yang disembah oleh masyarakat Arab hingga diutusnya Nabi Muhammad sebagai Rasul. Wakaf yang pertama kali dikenal adalah Masjid Quba yang terletak $5 \mathrm{~km}$ dari pusat kota Madinah. Rasulullah Saw membangun Masjid Quba pada tahun 1 Hijriyah atau 622 Masehi saat singgah di Quba sebelum melanjutkan perjalanan hijrah ke Madinah. Masjid Quba yang dibangun dari pelepah kurma, tanah liat, dan batu-batu gurun terlihat sangat sederhana dan hanya difungsikan untuk sholat, dzikir, dan berteduh saat siang hari pada waktu terik matahari. Masjid yang menjadi saksi sejarah awal mula kebangkitan Islam yang dimulai di Madinah tersebut memiliki sejumlah keutamaan diantaranya seperti yang disabdakan oleh Rasulullah Saw, "Shalat di Masjid Quba', (pahalanya) seperti umrah."(HR.Tirmidzi, no. 324 dan Ibnu Majah no. 1411. Al-Hafzh Abu Thahir mengatakan bahwa Hadits ini hasan).

Beberapa negara menjadikan wakaf sebagai salah satu pemasukan yang dapat membantu berbagai sektor pemerintah. Di negara-negara Islam seperti Mesir dan Arab Saudi, pranata wakaf telah didayagunakan dan memegang peranan yang sangat besar dalam menunjang dan mengembangkan berbagai aspek kehidupan umat Islam Khosyi'ah (2010). Wakaf di Mesir dikelola oleh Badan Wakaf Mesir yang berada di bawah Wizaratul Auqaf (Kementerian Wakaf). Manfaat yang dihasilkan dari wakaf tersebut tidak hanya dirasakan oleh masyarakat mesir sendiri tetapi juga masyarakat dunia secara umum. Salah satu harta aset wakaf yang cukup besar dan cukup dikenal di dunia Islam adalah Universitas al-Azhar yang hingga sekarang masih diminati oleh mahasiswa dari seluruh dunia untuk belajar ilmu-ilmu Islam. Universitas tersebut didirikan pada masa zaman Khilafah Fathimiyyah. Perkembangan pengelolaan harta wakaf di Negara Mesir sedari awal memang sangat mengagumkan, bahkan keberhasilan Mesir ramai dijadikan contoh bagi pengembangan pengelolaan wakaf di negara-negara lain Mu'allim (2015). Setiap tahun lembaga tersebut memberi beasiswa yang diperuntukkan mahasiswa asing yang belajar di Universitas Al-Azhar Kairo. Penerima beasiswa mencapai 7000 orang yang berasal dari berbagai negara, termasuk Indonesia sebagai salah satu negara penerima beasiswa paling banyak. Indonesia memiliki aset wakaf yang cukup besar. Jumlah aset tanah wakaf di Indonesia adalah sebanyak 377.548 lokasi dengan luas tanah mencapai 50.788,47 Ha. Namun, sangat disayangkan sebagian besar aset wakaf yang ada di 
Indonesia merupakan aset tidak bergerak dan tidak produktif. Sebanyak $44,44 \%$ berupa masjid, $28,36 \%$ berupa musholla, $10,66 \%$ berupa sekolah, 3,44\% berupa pesantren, 4,47\% berupa makam, dan 8,62\% berupa sosial lainnya Siwak (2020). Jawa Tengah menjadi provinsi dengan jumlah aset wakaf terbanyak dengan angka 98.774 lokasi Siwak (2020).

Indonesia juga memiliki yayasan pendidikan berbasis wakaf. Badan Wakaf adalah lembaga tertinggi dalam organisasi Balai Pendidikan Pondok Modern Darussalam Gontor. Lembaga ini berawal dari pewakafan Pondok Modern Darussalam Gontor, pada tanggal 28 Rabiul Awwal 1378/12 Oktober 1958, oleh para pendirinya (Trimurti) kepada Ikatan Keluarga Pondok Modern Darussalam Gontor yang diwakili oleh 15 orang yang dipercaya sebagai nazhir. Seluruh nazhir yang berjumlah 15 orang tersebut kemudian dibentuk menjadi lembaga Badan Wakaf Pondok Modern Darussalam Gontor Mu'allim (2015).

Kendala mendasar pengelolaan aset wakaf sekarang ini terletak pada titik manajemen pengelolaan yang dapat dikatakan telah bergeser dari jalan yang benar sehingga menyebabkan pengelolaan wakaf tidak lagi sesuai dengan tujuan awal disyariatkannya dalam Islam. Dikarenakan hal tersebut, perlu diadakan upaya memperbaiki yang bertujuan untuk membenahi pengelolaan wakaf dan menghilangkan keterpurukan manajemen wakaf akibat kelalaian atau buruknya manajemen yang dijalankan oleh Nazhir Ridwan (2012). Sehingga diperlukan terciptanya profesionalisme nazhir dalam mengelola harta wakaf, supaya wakaf memberikan dampak kesejahteraan sosial dan ekonomi masyarakat maka perlu memberdayakan wakaf, hingga dapat memberikan peningkatan kesejahteraan umat Islam pada khususnya dan masayarakat pada umumnya Ilyas (2017).

Aset wakaf yang dimiliki Indonesia akan sangat menebar kebermanfaatan jika para nazhir mengalokasikan sebagian aset wakaf yang dikelolanya menjadi dalam bentuk wakaf produktif seperti perkebunan, sawah, dan pertokoan. Salah satu solusi yang diharapkan dapat mengatasi kendala kemiskinan yaitu partisipasi aktif masyarakat dalam mengembangkan wakaf tunai atau pengelolaan wakaf dalam bentuk produktif. Jika potensi wakaf ini dapat dikoordinasikan serta dikelola dengan baik, maka hal ini dapat memberikan alternatif kontribusi penyelesaian positif atas masalah kemiskinan Purwanto (2017). Namun jumlah wakaf produktif atau wakaf investasi masih sangat sedikit. Masih sedikitnya temuan wakaf dalam bentuk investasi disebabkan oleh masih kurangnya kemampuan nazhir dalam mengelola wakaf dalam bentuk investasi. Nazhir ditemukan tidak mempunyai pemahaman dan kemampuan dalam berinvestasi wakaf, menyebabkan yang muncul di tengah-tengah masyarakat adalah wakaf-wakaf yang tidak memiliki nilai ekonomis yang produktif Furqon (2014).

Persoalan tentang kurangnya profesionalisme nazhir dalam mengelola aset wakaf masih sering ditemui terlepas dari telah diterbitkannya UU no. 41 tahun 2004 tentang wakaf. Meskipun di dalam undang-undang tersebut terutama di pasal 9 sampai 14 telah memuat secara rinci tanggung jawab serta hak dan kewajiban nazhir, cukup sering ditemukan di lapangan nazhir masih belum mengetahui secara pasti apa saja tanggung jawab, hak serta kewajibannya. Karena ketidaktahuan tersebut, akibatnya aset wakaf dikelola hanya sebatas 
pengelolaan tradisional, administrasi yang tidak rapi dan manajemen yang kurang baik.

Pengelolaan aset wakaf yang kurang baik mengakibatkan tidak tersampaikannya dengan maksimal tujuan-tujuan wakaf seperti pengentasan kemiskinan, pembangunan sarana ibadah, dan peningkaan kuantitas dan kualitas pendidikan. Padahal tentu saja ketika seorang wakif mewakafkan hartanya yang diinginkannya adalah kebermanfaatan sosial secara umum yang nantinya akan diberi ganjaran pahala tanpa terputus oleh Allah swt. sebagaimana hadits Rasulullah saw. Dari Abu Hurairah r.a. berkata, Rasulullah Saw. bersabda: "Apabila 'anak Adam itu mati, maka terputuslah amalnya, kecuali (amal) dari tiga ini: sedekah yang berlaku terus menerus, pengetahuan yang d manfaatkan, dan anak sholeh yang mendoakan dia." (HR Muslim).

Nazhir bahkan tidak hanya dituntut untuk mengelola aset wakaf tetapi juga untuk menciptakan inovasi-inovasi dalam manajemen aset wakaf. Dengan adanya inovasi modern di bidang manajemen aset wakaf maka nilai aset wakaf akan terjaga dan bahkan meningkat. Hal tersebut menyebakan manfaat akan semakin besar dan luas dirasakan dan juga secara otomatis membuat pahala sedekah jariyah bagi wakif makin banyak.

Peran nazhir dalam pengelolaan aset wakaf sangat vital. Apabila nazhir belum memahami secara pasti ilmu-ilmu tentang pengelolaan wakaf maka bisa dipastikan keberjalanan aset wakaf akan kurang maksimal dan bukan tidak mungkin aset wakaf akan mengalami penurunan nilai. Berdasarkan buku Fenomena Wakaf di Indonesia : Tantangan Menuju Wakaf Produktif Fauzia et al. (2016) mengungkapkan; nyatanya bukan menjadi sebuah alasan apabila aset sebuah harta wakaf berjumlah kecil, disaat potensi, kemampuan, serta pemahaman nazir sangat baik, maka lembaga wakaf akan berkembang dengan baik pula disebabkan oleh nazir yang selalu tergerak untuk mengembangkan harta wakaf yang dikelolanya. Lain halnya, apabila aset dan kemampuan seorang nazhir tidak memadai untuk mengembangkan harta wakaf.

Berdasarkan penjelasan diatas, maka penelitian ini akan menjawab beberapa pertanyaan penilitian, yaitu; bagaimana problematika nazhir sehingga masih kurang baiknya manajemen wakaf di Kota Semarang, bagaimana penerapan strategi oleh Badan Wakaf Indonesia agar terciptanya profesionalisme nazhir, apa kendala dan bagaimana solusi Badan Wakaf Indonesia dalam mengatur perwakafan dan nazhir di Kota Semarang.

\section{KAJIAN LITERATUR}

\section{Konsep Wakaf}

Secara bahasa, wakaf berasal dari bahasa arab yaitu "waqafa" yang memiliki arti menahan. Kata "al-Waqf" dalam bahasa Arab mengandung beberapa pengertian: Artinya : Menahan, menahan harta untuk diwakafkan, tidak dipindahmilikkan Direktorat Pemberdayaan Wakaf (2006).

Undang-undang No. 41 tahun 2004 bab 1 pasal 1 menyatakan bahwa wakaf adalah perbuatan hukum wakif untuk memisahkan dan/atau menyerahkan sebagian harta benda miliknya untuk dimanfaatkan selamanya atau untuk jangka waktu tertentu sesuai dengan kepentingannya guna keperluan ibadah dan/atau kesejahteraan umum menurut syariah. Dalam peristilahan syarak 
secara umum, wakaf adalah sejenis pemberian yang pelaksanaannya dilakukan dengan jalan menahan (pemilikan) asal (tahbisul ashli), lalu menjadikan manfaatnya berlaku umum. Yang dimaksud dengan tahbisul ashli adalah menahan barang yang diwakafkan itu agar tidak diwariskan, dijual, dihibahkan, digadaikan, disewakan dan sejenisnya. Sedangkan cara pemanfaatannya adalah menggunakan sesuai dengan kehendak pemberi wakaf (wakif) tanpa imbalan Kementerian Agama Republik Indonesia Direktorat Jenderal Bimbingan Masyarakat Islam Direktorat Pemberdayaan Wakaf (2013).

\section{Dasar Hukum Wakaf}

Al-Quran tidak menyebutkan secara langsung ketentuan dan perintah tentang wakaf, tetapi ada beberapa ayat dalam Al-Quran yang menurut para ulama menjadi dasar hukum wakaf, diantaranya :

Ali Imran (92)

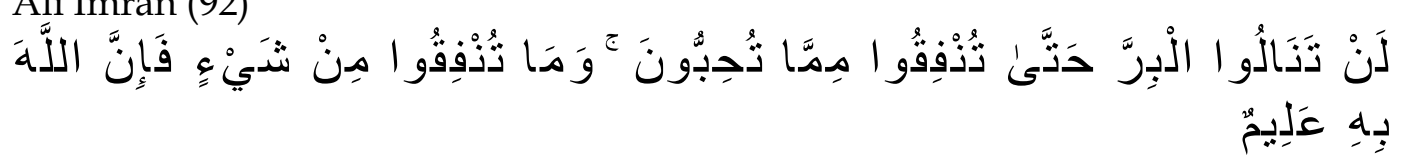

Artinya: "Kamu sekali-kali tidak sampai kepada kebajikan (yang sempurna), sebelum kamu menafkahkan sehahagian harta yang kamu cintai. Dan apa saja yang kamu nafkahkan maka sesungguhnya Allah mengetahuinya."

Al Baqarah (267)

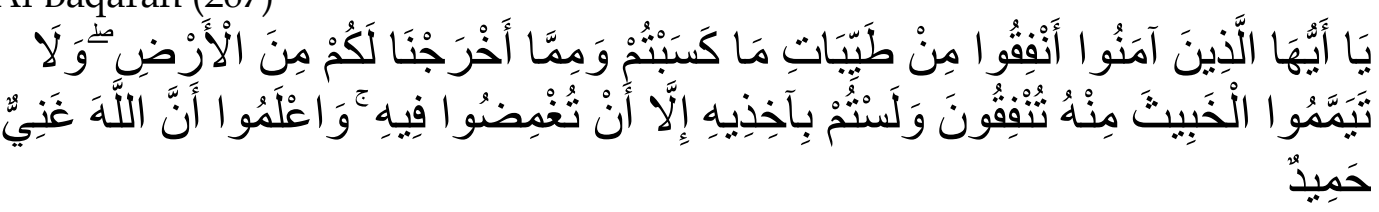

Artinya: "Hai orang-orang yang beriman, nafkahkanlah (di jalan allah) sebagian dari hasil usahamu yang baik-baik dan sebagian dari apa yang Kami keluarkan dari bumi untuk kamu. Dan janganlah kamu memilih yang buruk-buruk lalu kamu menafkahkan daripadanya, padahal kamu sendiri tidak mau mengambilnya melainkan dengan memincingkan mata terhadapnya. Dan ketahuilah, bahwa Allah Maha Kaya lagi Maha Terpuji."

Hadits Riwayat Muslim no. 1631

Dari Abu Hurairah ra., ia berkata bahwa Rasulullah Saw bersabda;

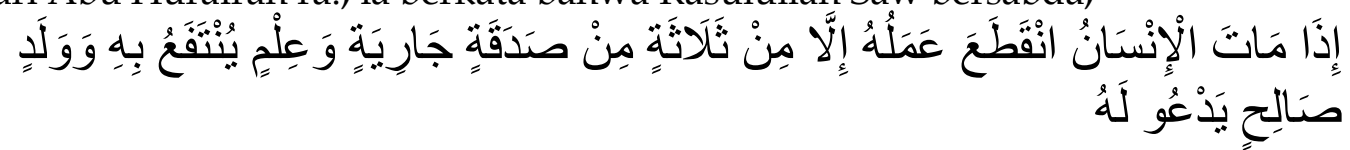

Artinya: "Jika seseorang meninggal dunia, maka terputuslah amalannya kecuali tiga perkara (yaitu): sedekah jariyah, ilmu yang dimanfaatkan, atau do'a anak yang shalih."

\section{Rukun dan Syarat Wakaf}

Rukun merupakan hal-hal yang harus ada untuk sahnya sebuah ibadah. Rukun wakaf diantara 4 mazhab kurang lebih sama, hanya ada tambahan dibeberapa mazhab. Adapun rukun wakaf menurut ulama Hanafiyah hanya sighah (ikrar atau akad) saja Bank Indonesia (2016). Ulama Syafi'iyah, Malikiyah, dan Hanabilah berpendapat rukun wakaf adalah: 
1. Wakif (orang yang memberikan harta wakaf)

2. Mauquf 'alaih (orang yang menerima wakaf atau tujuan wakaf)

3. Mal al-Mauquf (harta benda yang diwakafkan)

4. Shighah (ijab Kabul atau ikrar)

\section{Nazhir}

Nazhir meskipun tidak diikutsertakan oleh para Fuqoha sebagai salah satu dari rukun wakaf akan tetapi mempunyai peranan yang cukup menentukan dalam pengelolaan wakaf. Sesungguhnya harta wakaf adalah sebuah benda mati, hingga bernilai atau tidaknya, dan produktif atau tidaknya harta tersebut tidak bergantung pada benda tersebut, akan tetapi bergantung kepada pengelolanya atau nazhir. Banyak wakaf yang tidak terurus dan terbengkalai dikarenakan nazhir tidak dapat mengelolanya, tetapi disamping itu banyak pula wakaf yang memiliki nilai manfaat disebabkan oleh kerja keras dan kemampuan para pengelolanya atau dalam hal ini nazhir Furqon (2014). Ditinjau dari proses pemberdayaan dan pengelolaan harta wakaf, peran nazhir baik perseorangan ataupun organisasi dan badan hukum, sangat penting disebabkan yang mengelola wakaf adalah nazhir. Alasan tersebut membuktikan bahwa etos kerja dan pemberdayaan sumber daya manusia nazhir berpengaruh terhadap pemberdayaan wakaf Tiswarni (2014).

Secara bahasa nazhir termasuk kata berbentuk isim fa'il yang berasal dari kata nadzara yang memiliki arti penjaga, pemelihara, pengelola dan pengawas. Adapun secara istilah nazhir merupakan orang atau sekelompok orang dan badan hukum yang diberikan tugas oleh wakif (orang yang berwakaf) untuk melaksanakan pengelolaan harta wakaf Abbas (2017).

Undang-undang nomor 41 tahun 2004 menyatakan bahwa Nazhir adalah pihak yang menerima harta benda wakaf dari Wakif untuk dikelola dan dikembangkan sesuai dengan peruntukannya. Dimana undang-undang nomor 41 tahun 2004 membagi nazhir kedalam 3 bagian yaitu :

1. Nazhir perseorangan

2. Organisasi

3. Badan hukum

\section{Syarat-Syarat Nazhir}

1. Beragama Islam

Wakaf merupakan salah satu kegiatan ibadah dalam agama Islam, oleh karena itu seorang nazhir yang merupakan pengelola wakaf disyaratkan dari muslim sendiri.

2. Dewasa (baligh)

Anak kecil tidak sah untuk menjadi nazhir karena belum dapat dilakukan hukum atasnya dan dianggap belum cakap memikul tanggung jawab. 
3. Amanah

Nazhir harus merupakan seorang yang dapat dipercaya karena pekerjaannya berkaitan langsung dengan harta benda orang lain.

4. Memiliki Kemampuan Untuk Mengelola Wakaf

Nazhir dapat dikatakan merupakan pihak yang memiliki tanggung jawab paling besar terhadap aset wakaf yang dipercayakan pengelolaannya padanya, baik terkait pemeliharaan aset wakaf, ataupun terkait hasil pengelolaan serta usaha untuk pengembangannya.

\section{Tugas dan Wewenang Nazhir}

Tugas nazhir menurut undang-undang nomor 41 tahun 2004 adalah :

1. Melakukan pengadministrasian harta benda wakaf.

Pengadministrasian harta benda wakaf harus dilakukan sesuai standar dari institusi yang bersangkutan agar kelak disaat nazhir melakukan pelaporan aset wakaf dapat diterima dan didata dengan baik.

2. Melakukan pengelolaan dan pengembangan aset harta wakaf tepat selaras dengan tujuan, fungsi dan peruntukannya.

Sumber dana wakaf dituntut untuk harus terus dikelola; baik diperoleh dari dana khusus yang disiapkan pewakaf untuk pembangunan dan pengelolaan, ataupun harta wakaf yang siap dipergunakan secara langsung.

3. Melakukan pengawasan dan perlindungan harta wakaf.

Mengawasi dan melindungi aset harta wakaf dimaksudkan demi tujuan untuk menjaga berkurangnya nilai harta benda wakaf, baik karena peristiwa-peristiwa force majeur maupun karena kerugian/kegagalan investasi Megawati (2014).

4. Melaporkan pengelolaan aset wakaf kepada Badan Wakaf Indonesia

\section{METODE PENELITIAN}

Metode kualitatif digunakan pada penelitian ini sehingga data didapat melalui wawancara mendalam. Peneliti juga turun ke lapangan dan melakukan interaksi secara langsung dengan objek penelitian serta memahami apa tafsiran dan pikiran mereka terhadap pekerjaan yang merupakan tanggung jawabnya. Penelitian ini mencoba menggali peran strategi Badan Wakaf Indonesia dalam meningkatkan profesionalisme nazhir, maka pengumpulan data dilakukan dengan cara wawancara mendalam dan dokumentasi.

Penelitian ini menggunakan data primer dan data sekunder. Sumber data primer didapat dari informan yang diwawancara secara mendalam dengan tetap menggunakan pokok-pokok pertanyaan sehingga 
wawancara menghasilkan informasi yang akan diolah menjadi data yang akan digunakan dalam penelitian. Data sekunder adalah data yang didapat dari dokumen dan arsip resmi yang berkaitan dengan pengelolaan wakaf. Data sekunder disini bersifat data pendukung untuk menguatkan data primer yang telah didapat.

Pengumpulan data tidak hanya didapat dari wawancara secara mendalam dengan informan tetapi juga dari observasi lapangan, catatan lapangan, dan juga saat melakukan interaksi dengan lingkungan sekitar informan yang masih berhubungan dengan fenomena penelitian.

Teknik keabsahan data yang digunakan dalam penelitian ini adalah menggunakan teknik triangulasi. Proses triangulasi dilakukan saat peneliti sudah mendapat data penelitian, peneliti menggunakan sumber lain di luar data sebagai inspeksi terhadap data yang didapat apakah valid atau tidak.

\section{PEMBAHASAN}

\section{Latar Belakang Badan Wakaf Indonesia}

Badan Wakaf Indonesia (BWI) merupakan lembaga nasional bersifat independen yang didirikan berdasarkan lahirnya Undang-Undang Nomor 41 Tahun 2004 (Wakaf). Organisasi tersebut didirikan untuk mendorong pengembangan dan optimalisasi wakaf di Indonesia. BWI didirikan tidak untuk mengambil alih aset wakaf yang telah dikelola oleh nazhir (pengelola aset wakaf). BWI memberi dorongan dan dukungan kepada Nazhir agar dapat lebih baik dalam mengelola aset wakaf dan meningkatkan efisiensi produksi, sehingga memberikan manfaat yang lebih besar kepada masyarakat berupa pelayanan sosial, pemberdayaan ekonomi dan pembangunan infrastruktur umum. Lokasi BWI terletak di ibu kota negara, dan perwakilannya dapat dibentuk di provinsi, daerah, dan / atau kota sesuai kebutuhan.

BWI merupakan organisasi yang independen dalam mengembangkan wakaf di Indonesia dan dalam melaksanakan pekerjaannya tidak terpengaruh kekuatan apapun, dan bertanggung jawab jawab kepada komunitas masyarakat luas. Pembentukan Badan Wakaf Indonesia dimulai dengan pengembangan jumlah tanah wakaf dan inovasi wakaf yang tidak terdokumentasi dan dikelola dengan baik, sehingga untuk pengumpulan dan bimbingan data wakaf daerah, nazhir membutuhkan sosialisasi dan pelatihan. Berdirinya BWI menjadi awal dari kebangkitan gerakan wakaf. Ide filosofis wakaf sebagai lembaga Islam telah menjadi salah satu pendukung dari perkembangan masyarakat Islam Peradaban di Zaman Keemasan Islam saat ini.

Anggota BWI diangkat dan diberhentikan oleh Presiden. Masa jabatan adalah 3 tahun dan dapat dipilih kembali satu kali. Jumlah anggota BWI berkisar antara 20 hingga 30 orang yang berasal dari semua lapisan 
masyarakat. Anggota BWI pertama diusulkan ke Presiden oleh Menteri Agama. Periode kepengurusan berikutnya diusulkan oleh Panitia Seleksi yang terdiri dari BWI. Anggota perwakilan BWI diangkat dan diberhentikan oleh BWI. Struktur manajemen BWI terdiri dari komite penasihat dan badan pelaksana. Setiap ketua dipilih oleh ketua, dan ketua dipilih oleh anggota dan dipilih oleh anggota. Badan pelaksana adalah unsur penanggung jawab tugas, dan panitia pembina adalah berasal dari unsur pengawas.

\section{Perwakilan Badan Wakaf Indonesia (BWI) Jawa Tengah}

Pelaksanaan tanggung jawab dan wewenang BWI didukung penuh oleh perwakilan BWI provinsi di tingkat provinsi dan perwakilan BWI kota/kabupaten pada daerah tingkat dua. Perwakilan BWI Jawa Tengah dibentuk pada Oktober 2013. Perwakilan BWI provinsi memiliki kedudukan di ibu kota provinsi maka oleh sebab itu perwakilan BWI Jawa Tengah berkedudukan di Semarang.

Perwakilan BWI Provinsi memiliki tanggung jawab dan wewenang sebagai berikut:

1. Menerapkan aturan kebijakan dan menjalankan tupoksi tugas BWI pada tingkat provinsi.

2. Menjalin koordinasi dengan Kantor Wilayah Kementerian Agama dan lembaga terkait dalam perwakafan demi tujuan menjalani amanah tugas.

3. Melakukan pembinaan nazhir agar lebih mumpuni dalam melakukan pengelolaan dan pengembangan harta benda wakaf.

4. Bertindak secara internal dan eksternal atas nama perwakilan BWI provinsi dan bertanggung jawab atas mereka.

5. Melakukan pemutusan dan / atau penggantian nazhir tanah wakaf yang memiliki luas 1.000 meter persegi sampai dengan 20.000 meter persegi.

6. Menerbitkan sertifikat pendaftaran tanah wakaf Nazhir dengan luas tanah 1.000 meter persegi sampai dengan 20.000 meter persegi.

7. Menggelar peninjauan tanah wakaf yang luasnya minimal 1.000 meter persegi, menyarankan agar tanah tersebut ditetapkan kembali atau ditukar, dan hasilnya harus dilaporkan ke BWI.

8. Melaksanakan tugas lain yang diberikan oleh BWI.

\section{Perwakilan Badan Wakaf Indonesia (BWI) Semarang}

Perwakilan BWI Kota Semarang berdiri pada tahun 2017 berdasarkan Keputusan Badan Pelaksana Badan Wakaf Indonesia Nomor 075/BWI/PBWI/2016. Keputusan tersebut dikeluarkan sebagai tanggapan untuk Surat Kepala Kantor Kementrian Kota Semarang nomor 9212/KK.11.33/7/BA.03.2/2016 pada 22 Agustus 2016 Perihal 
Permohonan Pembentukan Perwakilan BWI Kota Semarang. Perwakilan BWI Kota Semarang berlokasi di Kantor Kementrian Agama Kota Semarang yang terletak di Komplek Islamic Center, Jl. Untung Suropati, Kalipancur, Kec. Ngaliyan, Kota Semarang, Jawa Tengah 50183.

Perwakilan BWI Kabupaten/Kota memiliki tanggung jawab dan wewenang:

1. Menjalankan kebijakan dan melaksanakan tugas BWI di tingkat daerah/kota;

2. Berkoordinasi dengan Kementerian Agama dan instansi terkait untuk melaksanakan tugas BWI kabupaten/kota;

3. Memberikan bimbingan kepada Nazhir tentang pengelolaan dan pengembangan aset wakaf;

4. Bekerja dibawah perwakilan BWI di dalam dan di luar daerah, mewakili dan bertanggung jawab atas perwakilan BWI;

5. Melakukan pencabutan dan penggantian Nazhir dengan luas tanah kurang dari 1.000 meter persegi (1.000 meter persegi);

6. Menerbitkan surat tanda bukti pendaftaran nazhir yang luas tanah wakaf kurang dari 1000 M2 (seribu meter persegi);

7. Melakukan peninjauan dan melaporkan usulan alokasi aset wakaf untuk perubahan bentuk tanah dengan luas kurang dari 1.000 meter persegi (1.000 meter persegi);

8. Melakukan peninjauan dan menyusun laporan atas usulan adanya penukaran/perubahan status aset wakaf (ruislag) berbentuk tanah yang memiliki luas kurang dari 1000 M2 (seribu meter persegi);

9. Menjalankan kewajiban-kewwajiban lain yang diamanahkan oleh Perwakilan BWI Provinsi.

\section{Peran Strategi Badan Wakaf Indonesia (BWI) dalam Meningkatkan Profesionalisme Nazhir Kota Semarang}

Faktor pengetahuan menjadi salah satu kendala utama dalam mengurai kelemahan nazhir disaat melaksanakan amanahnya sebagai pengelola wakaf. Cukup banyak ditemukan nazhir yang belum memiliki pemahaman tentang wakaf, bahkan tentang tugas dan tanggung jawabnya terhadap aset wakaf. Masih terbatasnya pengetahuan para nazhir mengakibatkan kurangnya kreatifitas dan kredibilitas manajemen wakaf.

Faktor yang menjadi kendala selanjutnya adalah faktor pembinaan yang diterima para nazhir. Nazhir memang telah mendapat pembinaan sesuai dari Undang-Undang nomor 41 Tahun 2004 tentang wakaf. Tapi, upaya tersebut masih tergolong minim meskipun pemerintah ataupun lembaga lain dan organisasi Islam yang aktif berkarya di masyarakat turut memberi pembinaan. Bisa dikatakan, permasalahan nazhir wakaf belum termasuk kedalam agenda pemberdayaan umat. Pembinaan dan pelatihan 
yang ada belum terstruktur secara jelas kurikulumnya, belum diadakan secara rutin dan tidak berkelanjutan secara mendalam.

Kendala berikutnya adalah perekrutan seorang nazhir. Kebanyakan nazhir yang diangkat masih atas dasar sukarela siapa yang berkenan dan siapa yang memiliki waktu luang. Sistem pemilihan nazhir oleh wakif masih sangat jauh dari yang seharusnya dilakukan. Baik nazhir perorangan ataupun yang berbentuk badan hukum, berkewajiban untuk didaftarkan pada Kantor Urusan Agama Kecamatan setempat apabila telah mendengar saran dari Camat dan Majelis Ulama kecamatan untuk mendapat pengesahan. Sebelum melaksanakan kewajiban tugas dan tanggung jawab, nazhir diwajibkan untuk mengucap sumpah di depan Kepala Kantor Urusan Agama Kecamatan dengan disaksikan sekurangkurangnya 2 orang saksi. Terkait jumlah nazhir yang diizinkan untuk satu unit perwakafan yaitu terdiri atas 3 (tiga) orang dan sebanyak-banyaknya 10 (sepuluh) orang yang diangkat oleh kepala Kantor Urusan Agama Kecamatan atas saran Majelis Ulama Kecamatan dan camat setempat Khosim dan Busro (2018).

Faktor imbalan menjadi kendala lainnya dalam permasalahan nazhir wakaf. Sesuai aturan dalam Undang-Undang nomor 41 Tahun 2004, nazhir berhak mendapat imbalan (ujrah) sebesar 10\% dari perolehan hasil pengelolaan wakaf. Namun, keadaan di lapangan membuktikan bahwa cukup sering ditemukan nazhir menerima imbalan semata-mata atas dasar kebijakan wakif atau lembaga yang mengurus wakaf setempat. Pada umumnya imbalan atau upah yang diterima nazhir tersebut cukup rendah sehingga nazhir harus mencari cara lain agar kebutuhannya terpenuhi. Hal semacam ini juga yang menjadi faktor tidak adanya motivasi kepada nazhir untuk bekerja lebih baik dan lebih serius dalam mengelola wakaf. Hasil wawancara yang dilakukan kepada informan (Perwakilan BWI Jawa Tengah) mengatakan bahwa untuk saat ini BWI fokus untuk melakukan penertiban terhadap administrasi dan regulasi aset wakaf yang ada. Penertiban tersebut dilakukan dengan alasan masih banyak aset wakaf di Kota Semarang yang belum memiliki sertifikat tanah yang jelas ataupun belum memenuhi persyaratan legalisasi menurut hukum perundangundangan yang berlaku.

Informan juga mengatakan dalam wawancara kendala tersebut merupakan salah satu permasalahan yang menjadi fokus utama Perwakilan BWI Jateng dalam menertibkan administrasi aset wakaf. Sebab menurutnya, apabila nazhir sudah paham akan pentingnya administrasi dan legalisasi aset wakaf maka aset wakaf akan dapat lebih dimaksimalkan pengelolaannya. Bukan hanya dipertahankan nilai asetnya tetapi juga dapat dibuat menjadi wakaf produktif yang masih sangat jarang keberadaannya. 
Banyaknya aset wakaf berupa tanah yang masih belum memenuhi legalitas menjadi tantangan tersendiri bagi Perwakilan BWI Kota Semarang. Permasalahan tersebut juga mengakibatkan masih belum ditemukannya aset wakaf yang benar benar produktif dan bermanfaat bagi masyarakat luas. Data dari sistem informasi wakaf menyebutkan bahwa di Kota Semarang terdapat 1537 aset wakaf dengan luas total 90,54 Ha. Dari seluruh aset wakaf tersebut yang sudah bersertifikat sejumlah 844 dengan luas total 59,85 Ha dan belum bersertifikat sebanyak 693 dengan luas total 30,69 Ha.

Banyaknya aset wakaf yang belum bersertifikat tersebut disebabkan oleh beberapa faktor, salah satunya nazhir wakaf yang kurang tanggap terhadap administrasi dan legalitas aset wakaf yang diurusnya. Nazhir yang seharusnya melakukan tugasnya sebagaimana yang tercantum dalam Undang-Undang no.41 Tahun 2004 tidak memenuhi tanggung jawabnya sebagai pengelola aset wakaf.

Kemudian dalam hal ini informan (perwakilan BWI Jawa Tengah) mengatakan bahwa masih banyak sekali aset wakaf yang belum mendapat kontrol pengawasan sehingga belum masuk pada pendataan BWI. Guna mengatasi hal ini diharapkan masyarakat terkhusus masyarakat muslim ikut andil dan memperhatikan perwakafan di lingkungannya. Akan lebih baik jika masyarakat ikut serta melaporkan apabila terdapat aset wakaf yang terbengkalai ataupun belum memiliki nazhir yang mengurusnya. Kurangnya kepedulian dan pemahaman masyarakat terhadap status harta wakaf yang perlu perlindungan dan pemanfaatan menjadi faktor tambahan kurang efektifnya keberadaan aset wakaf di Kota Semarang. Bahkan, sebagian dari masyarakat menilai objek wakaf bukan merupakan hak milik mereka sehingga menimbulkan rendahnya rasa kepedulian terhadap pengelolaan objek wakaf. Padahal apabila terdapat seseorang yang mewakafkan hartanya, secara otomatis praktik wakaf yang dilakukannya mengakibatkan lepasnya kepemilikan pribadi wakaf dan menjadikannya sebagai objek kemanfaatan umum. Hal tersebut disebabkan masih terlalu rendahnya pengetahuan masyarakat tentang praktik wakaf dan juga rendahnya ilmu pengetahuan nazhir wakaf itu sendiri.

Banyak juga ditemukan keadaan dimana kemampuan nazhir tidak sesuai dengan aset wakaf yang dikelolanya. Harusnya, kapabilitas seorang nazhir sesuai dengan aset wakaf yang dikelolanya sehingga manfaat yang dihasilkan maksimal dan tidak ada kendala dalam mengelola aset wakaf. Sebagai contoh, apabila terdapat seorang nazhir yang memiliki kemampuan mumpuni dalam bidang pertanian, maka hendaknya nazhir tersebut mengelola tanah wakaf yang berpotensi untuk dikembangkan menjadi lahan pertanian. Maka dari produk-produk pertanian yang dihasilkan dapat menjadi manfaat bagi masyarakat sekitar. Begitu pula 
jika ada nazhir yang memiliki kapabilitas dibidang investasi seperti saham syariah, reksadana, emas dan logam mulia maka nazhir tersebut bisa mengembangkan wakaf dibidang investasi tersebut. Dengan begitu alur wakaf menjadi lebih dinamis dan luas kebermanfaatannya. Cakupan sosial dari wakaf itu sendiri juga semakin luas yang pada akhirnya menarik calon wakif dari kalangan yang berbeda untuk mewakafkan sebagian hartanya.

Masa bakti nazhir juga sangat tidak pasti hanya berdasarkan kemampuan nazhir itu sendiri meskipun menurut peraturan pemerintah masa bakti nazhir adalah 5 tahun. Peraturan dan persyaratan pengangkatan nazhir masih sangat sulit diterapkan kepada masyarakat karena masih seringnya ada anggapan nazhir merupakan tokoh agama atau masyarakat dan masa pengurusannya terhadap aset wakaf tersebut berlaku seumur hidup. Hal itu disebabkan oleh beberapa factor, yakni:

1. Sulitnya perwakilan BWI Jateng memetakan seluruh nazhir yang berada di Kota Semarang dikarenakan kemampuan jangkauan yang belum maksimal. Sehingga hubungan BWI dengan para nazhir kurang terkoordinasi dengan baik.

2. Nazhir tidak serius dalam menjalankan amanah yang diberikan padanya, dilihat dari banyaknya tanah wakaf yang belum bersertifikat. Seharusnya para nazhir mendaftarkan aset wakaf yang dikelolanya ke Badan Pertahanan Nasional untuk mendapat sertifikat Hak Milik Wakaf.

3. Masih banyak nazhir baik perseorangan, badan hukum, dan organisasi yang tidak melaporkan dengan terjadwal kinerja pengelolaan dan manajemen aset wakaf yang dikelolanya.

4. Perwakilan BWI Kota Semarang terhitung masih baru dibentuk sehingga masih perlu penyesuaian lingkup kerja yang efektif.

5. Fasilitas Perwakilan BWI Kota Semarang masih sangat terbatas terutama dalam hal infrastruktur. Terlihat dari kantor perwakilan yang masih bersatu dengan kantor kementrian agama.

6. Anggaran yang diberikan pemerintah dirasa masih kurang. Anggaran yang ada masih sangat kurang dan tidak memadai untuk mengembangkan aset wakaf.

\section{Strategi BWI dalam Peningkatan Profesionalisme Nazhir}

Seorang nazhir yang profesional dalam melakukan manajemen aset wakaf dituntut untuk mengambil acuan prinsip pada kaidah-kaidah manajemen modern. Kata profesional diambil dari kata dasar profesi yang memiliki arti sebuah pekerjaan di mana seseorang hidup dari melakukan pekerjaan dan tugas tersebut dengan mengandalkan keahlian, melibatkan keterampilan dan membutuhkan komitmen yang kuat Ilyas (2017). 
Nazhir profesional mereka mengandalkan pengetahuan dan keterampilan profesional tingkat tinggi untuk bekerja penuh waktu dan memiliki komitmen tinggi untuk pekerjaan mereka. Jika Nazhir terlibat dalam suatu pekerjaan, maka dia dianggap profesional karena dia ahli di bidangnya dan mencurahkan waktu, pikiran dan tenaganya untuk pekerjaan tersebut. Oleh karena itu, para profesional memiliki komitmen yang kuat terhadap pekerjaannya. Komitmen pribadi semacam ini membawa tanggung jawab yang sangat besar dan tinggi pada pekerjaannya Baharuddin \& Iman (2018).

Aspek yang harus dimiliki agar seorang nazhir dapat disebut profesional telah dirumuskan oleh Departemen Agama RI Direktorat Pengembangan Zakat dan Wakaf Direktorat Jenderal Bimbingan Masyarakat Islam dan Penyelenggaraan Haji (2005). Aspek tersebut adalah:

1. Memiliki keahlian dan keterampilan khusus agar dapat melakukan pekerjaan dengan baik.

Keahlian dan keterampilan ini biasanya didapat dari pendidikan, pelatihan ataupun pengalaman dalam jangka waktu tertentu. Ilmu, keahlian dan keterampilan ini membantu orang yang profesional mengenali dengan baik persoalan tersebut dalam pekerjaannya. Dengan begitu, orang tersebut dapat merumuskan solusi yang tepat yang akan mengakibatkan keberhasilan mutu yang baik.

2. Memiliki komitmen moral.

Profesi nazhir merupakan profesi pelayanan sosial. Profesi pelayanan sosial sangat memerlukan komitmen moral sebagai kode etik profesi. Etika dalam bentuk ini merupakan sebuah aturan yang harus dipegang dalam menjalankan amanah pekerjaan. Kode etik profesi ini juga ditujukan demi melindungi masyarakat dari kerugian dan kelalaian. Terlepas dari sengaja ataupun tidak disengaja, sehingga bisa melindungi orang yang memegang profesi tersebut dari tingkah perilaku yang tidak baik.

3. Hidup dari profesi yang dijalani

Orang yang profesional dibayar dengan upah dan gaji yang sesuai sebagai timbal balik dari usahanya mengerahkan tenaga, pikiran, waktu, keahlian, dan keterampilan. Dengan dituntutnya nazhir menjalani pekerjaan dengan profesional, maka nazhir juga harusnya dapat menghidupi dirinya sendiri dan keluarga dari profesinya tersebut. Nazhir seharusnya dijamin dapat mencukupi kebutuhan sehari-harinya tanpa perlu mencari tambahan pemasukan di luar pekerjaannya.

4. Mengabdi kepada masyarakat

Berkaitan dengan komitmen moral yang termasuk dalam kode etik profesi dimana orang pemegang profesi tertentu seperti nazhir lebih mendahulukan kepentingan masyarakat dari kepentingan individu. 
5. Legalisasi

Perizinan atau legalisasi sangat penting bagi profesi yang menyangkut kepentingan masyarakat luas dan terkait dengan nilai kemanusiaan. Setiap nazhir harus disahkan dan diangkat dengan resmi agar menimbulkan kepercayaan masyarakat.

Informan dalam wawancara menjelaskan nazhir juga dituntut harus kreatif dan aktif dalam mengurus aset wakaf. Apabila nazhir kurang memiliki kemampuan dalam mengembangkan aset wakaf maka nazhir dapat mengajak kerjasama pihak lain yang dapat membantu mengelola dan mengembangkan aset wakaf. Sebagai contoh, jika ada sepetak lahan wakaf yang tidak produktif, namun berpotensi untuk dijadikan lahan pertanian, maka nazhir bisa mengajak sekelompok orang yang ahli dibidang pertanian untuk membantu mengembangkan lahan tersebut menjadi lahan pertanian. Nazhir juga perlu untuk mengetahui praktik perwakafan di berbagai negara terutama negara yang sudah maju perwakafannya seperti Mesir, Bangladesh, Turki dan lain-lain. Dengan demikian nazhir dapat menerapkan inovasi yang dilakukan oleh negara lain dalam mengembangkan wakaf di Indonesia.

Memahami ilmu pengetahuan tentang ekonomi Islam juga menjadi nilai tambah bagi seorang nazhir. Instrumen keuangan syariah dewasa ini sedang mengalami perkembangan. Disisi lain, wakaf merupakan salah satu lembaga ekonomi Islam yang memiliki potensi untuk dikembangkan. Karena alasan tersebut, sudah selayaknya seorang nazhir terutama nazhir yang berupaya mengembangkan aset wakaf yang dikelolanya dituntut untuk paham akan ekonomi Islam dan instrument keuangan syariah yang mengikutinya. Ilmu ekonomi Islam juga akan sangat berguna bagi nazhir, karena disaat akan mengelola keuangan selain diharuskan secara profesional tetapi juga harus sesuai dengan prinsip-prinsip syariah. Begitu pula saat nazhir akan melakukan investasi dana wakaf, maka investasi yang dilakukan baik berupa investasi jangka panjang, menengah, ataupun pendek diharuskan mengikuti prinsip-prinsip syariah. Hal tersebut mutlak harus dilakukan karena aset wakaf merupakan harta yang akan disalurkan manfaatnya kepada masyarakat luas dan pahalanya mengalir kepada wakif, sudah tentu kehalalan harta benda wakaf tersebut menjadi syarat agar diterimanya amalan wakaf seorang wakif.

Informan dalam wawancara dengan penulis menjelaskan bahwa dalam hal tugas BWI sebagai pembina nazhir, telah terdapat divisi pembinaan nazhir dalam tubuh BWI. Divisi tersebut bertugas untuk mencetak profesionalisme nazhir. Tanggung jawab divisi tersebut mencakup nazhir peorangan, organisasi dan juga nazhir badan hukum. Program kerja dari divisi tersebut adalah:

1. Membuat silabus ataupun komponen pembelajaran dalam pelatihan nazhir. 
2. Mengadakan pelatihan, seminar, atau kelas untuk nazhir.

3. Membuat standarisasi etika kerja dan profesionalisme nazhir.

4. Membuat pendataan dan pemetaan para nazhir.

Salah satu strategi yang diutarakan informan demi mendapat kepercayaan masyarakat terhadap wakaf adalah memberi percontohan kepada masyarakat melalui wakaf produktif yang sudah berhasil. Dengan adanya pembuktian kepada masyarakat umum bahwa wakaf bisa memberi manfaat wakif akan termotivasi untuk berwakaf. Rencana strategi semacam ini perlu keberanian, keuletan, profesionalisme dari seorang nazhir sehingga aset wakaf yang dikelola menghasilkan hasil nyata yang mampu dijadikan pembuktian kepada masyarakat luas. Setelah mendapat kepercayaan masyarakat, maka kemudian dilakukan sosialisasi tentang wakaf secara utuh dimulai dari rukun dan syarat wakaf, harta benda yang bisa diwakafkan hingga hukum dan perundang-undangan wakaf yang berlaku. Alur strategi semacam ini diharapkan tepat sasaran dan dapat merubah kondisi perwakafan di Jawa Tengah dan Kota Semarang khusunya. Banyaknya harta wakaf yang dikelola secara tidak profesional yang pada akhirnya bersengketa ditangan ahli waris wakif membuat masalah tersendiri dimata masyarakat. Masyarakat menjadi tidak percaya dan ragu untuk mewakafkan hartanya karena melihat banyaknya pengelolaan wakaf yang tidak baik dan berjalan tidak sesuai fungsi dan tujuan wakaf.

Keputusan yang dibuat oleh badan wakaf dianggap tepat guna mengandung pengetahuan dasar tentang wakaf, dan panduan strategi produksi serta distribusi hasil untuk mencapai tujuan wakaf sebanyak mungkin Kasdi (2014). Alur strategi semacam ini sangat berpatokan kepada profesionalisme nazhir untuk dikembangkan di aset wakaf yang sesuai. Dengan adanya pendataan dan pemetaan nazhir wakaf yang mumpuni oleh BWI diharapkan wakif dapat memilih nazhir yang sesuai.

\section{KESIMPULAN}

Setelah dilakukan kajian, observasi dan analisis mengenai Peran Strategi Badan Wakaf Indonesia (BWI) dalam Meningkatkan Profesionalisme Nazhir Kota Semarang didapat hasil bahwa:

1. Kendala seputar perwakafan di Kota Semarang adalah masih banyak aset wakaf yang berdiri tanpa adanya legalisasi ataupun tanpa administrasi yang lengkap. Kondisi seperti itu disebabkan kurangnya pemahaman nazhir terhadap tanggung jawabnya mengelola aset wakaf.

2. Perwakilan BWI Jawa Tengah memfokuskan arah perbaikan perwakafan melalui penertiban administrasi aset wakaf yang ada. Upaya untuk melakukan legalisasi terhadap seluruh aset wakaf yang 
ada di Kota Semarang terus dilakukan atas dasar landasan UndangUndang No. 41 Tahun 2004.

3. Pelatihan yang didapat para nazhir wakaf Kota Semarang tergolong masih belum cukup untuk menciptakan nazhir yang profesional. Masih banyak nazhir wakaf yang hanya mengelola tanpa memperhatikan kewajibannya sebagai pengelola wakaf menurut aturan hukum yang berlaku.

\section{DAFTAR PUSTAKA}

Baharuddin, A. Z., \& Iman, R. Q. (2018). Nazir Wakaf Profesional, Standarisasi dan Problematikanya. Li Falah: Jurnal Studi Ekonomi Dan Bisnis Islam, 3(2), 62-74.

Bank Indonesia, \& UNAIR. (2016). Wakaf: Pengaturan dan Tata Kelola yang Efektif. In Seri Ekonomi dan Keuangan Syariah.

Furqon, A. (2014). Kompetensi Nazhir Wakaf Berbasis Social Entrepreneur (Studi Kasus Nazhir Wakaf Bisnis Center Pekalongan). Penelitian $L P 2 M, 44$.

Ilyas, M. (2017). Profesional Nazhir Wakaf dalam Pemberdayaan Ekonomi. Jurnal Al-Qadau: Peradilan Dan Hukum Keluarga Islam, 4(1), 71.

Kasdi, A. (2014). Peran Nadzir Dalam Pengembangan Wakaf. Jurnal Zakat Dan Wakaf, 1(2), 213-226.

Khosim, A., \& Busro. (2018). Konsep Nazhir Wakaf Profesional dan Implementasinya di Lembaga Wakaf NU dan Muhammadiyah. AlAwqaf: Jurnal Wakaf Dan Ekonomi Islam, 11(1), 49-74.

Khosyi'ah, S. (2010). Wakaf dan Hibah Perspektif Ulama Fiqh dan Perkembangannya di Indonesia.

Megawati, D. (2014). Pengelolaan Dan Pengembangan Wakaf Produktif Di Kota Pekanbaru. Hukum Islam, XIV(1), 104-124.

Mu'allim, A. (2015). Pengaruh Pengelolaan Wakaf di Mesir Terhadap Pengelolaan Harta Wakaf Pendidikan di Indonesia (Studi terhadap Ijtihad dalam Pengelolaan Wakaf Pendidikan di UII dan Pondok Modern Gontor). Akademika, 20.

Nissa, C. (2017). Sejarah, Dasar Hukum Dan Macam-Macam Wakaf. Jurnal Keislaman, Kemasyarakatan E Kebudayaan, 18(2), 205-219.

Purwanto. (2017). Hambatan Dalam Pengelolaan Wakaf Produktif. Wahana Islamika: Jurnal Studi Keislaman, 3.

Ridwan, M. (2012). Nazhir Profesional Kunci Kesuksesan Wakaf Produktif. Muqtasid: Jurnal Ekonomi Dan Perbankan Syariah, 3(1), 91.

Tiswarni. (2014). Peran Nazhir Dalam Pemberdayaan Wakaf (Tinjauan Terhadap Strategi Pemberdayaan Wakaf Badan Wakaf Alquran Dan Wakaf Center). Al-'Adalah, XII(2), 409-426. 